\title{
THE THEORY \\ AND MEASUREMENT OF ELASTICITY \\ OF SUBSTITUTION \\ IN INTERNATIONAL TRADE ${ }^{1}$
}

A number of empirical studies attempting to measure the elasticity of substitution in the international trade of competing countries have appeared in the postwar period ${ }^{2}$. These studies have had in mind such important problems as the effects of devaluation, and the determination of a country's price competitiveness and hence its share of world and regional export markets. While the studies have been subjected to severe criticism on statistical grounds ${ }^{3}$, comparatively less disagreement has been expresscd with regard to the theoretical base upon which their empirical work rests ${ }^{4}$. It is the purpose of the present paper to question the soundness of this base. In particular it will be argued that in computing elasticities of substitution to explain changes in trade, studies which rely upon relative export unit values derived from observations in recorded statistics are of doubtful signifcance.

\section{I}

The theoretical weakness which is characteristic of the empirical studies can be illustrated by reference to Raymond E. Zelder's time

1. Mr. Stern would like to thank the Columbia University Council for Research in the Social Sciences for its support of research which is connected in part with this paper.

2. A convenient annotated bibliography of these and related studies can be found in H.S. Cheng, "Statistical Estimates of Elasticities and Propensities in International Trade: A Survey of Published Studies", Staff Papers, Vol.virr, April I959.

3. See in particular G.H. Orcutt, "Measurement of Price Elasticities in International Trade", Review of Economics and Statistics, Vol. xxxir, May 1950; also H.S. Chene, op.cit., p. 108.

4. The major criticisms expressed have related primarily to the neglect of changes in income and in the prices of related commodities. For a discussion of these points, together with relevant references, see ARNold G. HARBerger, "Some Evidence on the International Price Mechanism", Gournal of Political Economy, Vol. Lxv, December 1957, pp.512-13. 
series estimates of thirty-nine elasticities of substitution between United States and United Kingdom exports of manufactured commodities for $192 \mathrm{I}-1938^{5}$. Mindful of the underestimates obtained by usual least squares procedure, Zelder used an estimating equation of the form: $\log \left(q_{1} / q_{2}\right)=A+B \log \left(p_{1} / p_{2}\right)$, where $\left(q_{1} / q_{2}\right)$, the relative export quantities, are to be explained by $\left(p_{1} / p_{2}\right)$, the relative export unit values. The regression coefficient, $B$, is interpreted as a lower-limit estimate of the relevant elasticity of substitution. $\mathrm{He}$ obtained estimates which ranged (excluding two positive ones) from -0.08 for cotton yarn to $-5.5^{2}$ for motorcycles. Of the thirty-seven negative estimates, all but four were greater than $I$ in absolute value. On the basis of these elasticities it was concluded that relative prices exercised an important influence upon the export performance of the competing countries ${ }^{\mathrm{B}}$.

The validity of this conclusion, however, obviously depends upon the meaningfulness of the price observations used to explain the relative quantities. It is our contention that these price observations have little or no explanatory significance ${ }^{7}$, for there is no reason to believe that the observed price relatives, computed from the recorded information available, accurately reflect the prices differentials which are in fact responsible for the changes observed in the export market shares. This is because of the tendency of the actual prices of substitutable goods to move in sympathy with one another. As a consequence, it is not possible to obtain from the actual, recorded

5. RAYmond E. ZELDER, "Estimates of Elasticities of Demand for Exports of the United Kingdom and the United States, I92 I-38', Manchester School, Vol. Xxvi, January 1958, p. $3^{6}$. Zelder's results are also reproduced in Arnold C. Harberger, op.cit., p.513. Time series elasticities of substitution have also been computed by many other investigators; see H.S. Cheng, op.cit., references (6), (7), (12), (14), (22), (28), and (37).

6. Translating his results into demand elasticities for total exports of about -3 for both countries, Zelder concludes further (p. 44) that moderate devaluations will be effective in correcting balance of payments deficits.

7. This is quite apart from the well known statistical defects inherent in the use of export unit values. These defects relate to the familiar index number problems encountered whenever a basket of goods is used in lieu of individual commodities. Differences in quality, commodity classification, and product mix are obscured when export unit values are employed. An increase in a country's export unit values, for example, may simply reflect a shift toward higher quality goods or a "superior" mix, instead of an increase in export prices. 
price observations the ex-ante or "impact" price data which are necessary for the computation of the "true" elasticities of substitution.

This can be brought out most clearly by examining a case in which we assume free trade, costless exchange, and perfect competition in a three country world, with supplies of some hypothetical export good, $X$, which is produced under identical conditions in two of the countries, $A$ and $B$, for export to the third country, $C^{8}$. We assume further that $X$ is a perfectly homogeneous good, and that $A$ and $B$ have equal shares in $C$ 's market. This is illustrated in Chart I.

Chart I

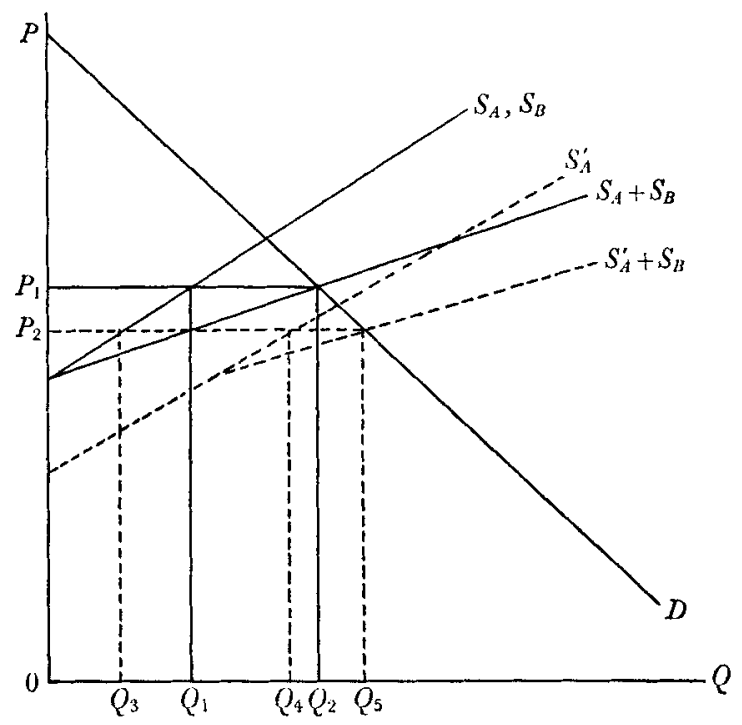

The equilibrium price and quantity, $P_{1}$ and $Q_{2}$, are obtained by the intersection of $C$ 's demand schedule with the total supply schedule, $S_{A}+S_{B} . A$ and $B$ each supply $0 Q_{1}$ of the total, $0 Q_{2}$. Suppose that productivity in $A$ 's export industry increases by 25 per cent, thereby shifting its supply schedule to $S_{A}^{\prime}$. If it is assumed that $B$ 's supply schedule remains fixed at $S_{B}$, the new total supply schedule will be $S_{A}^{\prime}+S_{B}$. This corresponds to an equilibrium price and quantity of $P_{2}$ and $Q_{5}$, with $A$ supplying $0 Q_{4}$ and $\mathrm{B}, 0 Q_{3}$. This accords with

8. Income effects and cross-elasticities of demand for other related goods will be ignored in all that follows. 
our a priori expectation; as a consequence of the relative reduction in $A$ 's cost of production, $A$ 's share of the market has increased, while that of $B$ has declined.

The question that presents itself now is whether it is possible to estimate the elasticity of substitution from the observed data. If a perfect frictionless market with instantaneous adjustment is assumed, the answer to this question is manifestly no. The observed new equilibrium price, $P_{2}$, is identical for $A$ and $B$ exports, although the observed quantities have changed ${ }^{9}$. Our price observations could thus give us no explanation for the observed changes, for when the price ratio between the exports of the two countries is unity, the export quantity relative could range from zero to infinity ${ }^{10}$. It is evident therefore that it would be meaningless to attempt to compute an elasticity of substitution under these circumstances. The reason for this is that the observed price data reflect the outcome of the operation of market forces, and thus do not reveal the impact price differentials which set these forces into motion and which are required to compute the true elasticity of substitution.

Computed elasticities of substitution are no more meaningful when the homogeneity assumption is dropped. Consider, for example, a case in which $A$ and $B$ produce different but related goods, $X_{A}$ and $X_{B}$, for export to $C$. This case is illustrated in Chart 2, where the equilibrium prices and quantities are $P_{A}$ and $Q_{A}$ for country $A$, and $P_{B}$ and $Q_{B}$ for country $B$. Now assume a 25 per cent increase in productivity in $A$, shifting $A$ 's supply schedule to $S_{A}^{\prime}$, with a new

9. An analogue for an occurence of this kind appears in the work of D.J. Morgan and W.J. Corlett, "The Influence of Price in International Trade: A Study in Method", Fournal of the Royal Statistical Society, Series A, Vol. cxrv, Part III, p. 339, where correlations of over 0.98 were found between price series of particular grades of wheat and also of particular grades of butter imported by the United Kingdom.

Io. It is possible that given certain slopes and positions of the two country's supply schedules, an elasticity of substitution equal to infinity would be obtained if country $B$ 's exports fell to zero in the light of the price decline induced by the assumed shift in $A$ 's supply schedule. The observed price data would still not reveal, in any event, the price differences which brought about the observed changes in quantity. An infinite elasticity of substitution would also be obtained if there was no change in country $B$ 's export price when $A$ 's supply schedule shifted. But it is exactly our argument that B's export price must change instantaneously and be identical in this example to $A$ 's. 


\section{Chart 2}

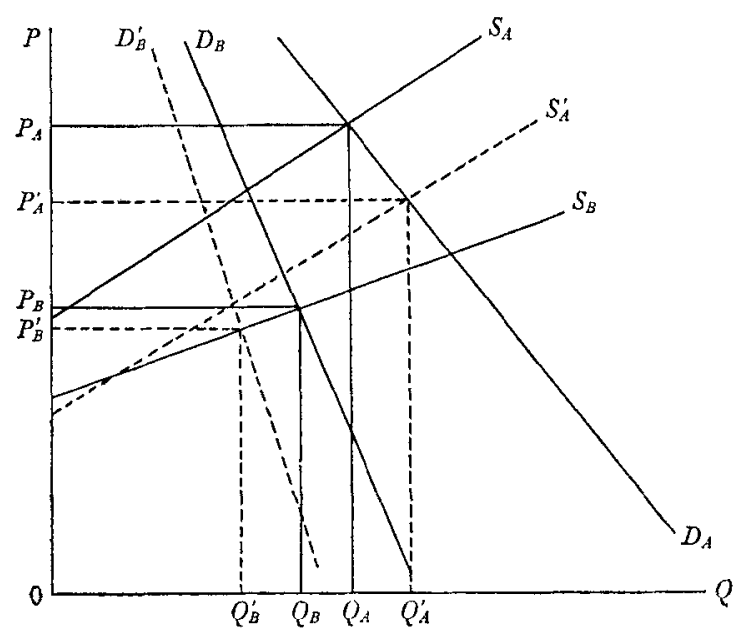

equilibrium at $P_{A}^{\prime}$ and $Q_{A}^{\prime}$. In view of the assumption that $B^{\prime}$ 's exports are substitutable for $A$ 's, an increase in the quantity demanded of imports from $A$ will be associated with a decline in the demand for imports from $B$, the extent of this decline being determined by the cross-elasticity of demand of $X_{A}$ and $X_{B}$. Suppose, therefore, that the demand for $B$ 's exports declines to $D_{B}^{\prime}$, with $P_{B}^{\prime}$ and $Q_{B}^{\prime}$ the resulting equilibrium price and quantity of $B$ 's exports. It would appear at first sight that the observed results are in accord with theoretical expectations; the narrowing of relative prices from $0 P_{A} / 0 P_{B}$ to $0 P_{A}^{\prime} / 0 P_{B}^{\prime}$ is associated with a change in favor of $A$ from $0 Q_{A} / 0 Q_{B}$ to $0 Q_{A}^{\prime} / 0 Q_{B}^{\prime}$. The elasticity derived from these observations need bear no relationship to the true one ${ }^{11}$, however, unless it is assumed that the elasticity of substitution is constant at every point, or that the elasticity of $B$ 's supply schedule is infinite. But we can see no theoretical justification for either of these assumptions ${ }^{12}$.

I 1. That is, the elasticity of substitution computed on the basis of the impact price differential and the consequent changes in export market shares, with $B$ 's export price assumed unchanged.

I2. A constant elasticity assumption is implied by the logarithmic transformation of the estimating equation of relative quantities and relative prices. G.D.A. MacDougall, "British and American Exports: A Study Suggested by 
It is not difficult to demonstrate, moreover, that the narrowing of the price differential obtained above was due to the manner in which the supply and demand curves were drawn. By altering the elasticities and positions of these curves, it is possible to obtain price differences greater than or equal to the original differences. A widening of price differentials is illustrated in Chart 3 , where the demand schedules are drawn as in Chart 2, but where the supply schedule for country $B$ is assumed to be more inelastic relative to that for $A^{13}$. On the basis of these results, an investigator would conclude that $A$ 's export market share increased despite an adverse movement of price differences. This anomalous result is attributable to the fact that the observed data reflect the outcome of the operation of market forces rather than the disequilibrating price differentials which set these forces into motion.

The preceding analysis suggests that the theoretical objections to the use of observed prices are as relevant for less homogeneous goods as for goods which are highly substitutable. For primary products, which are relatively homogeneous and widely traded, one can observe few price differences through time which cannot be traced to differences in quality, costs of transportation, or similar phenomena. It is an empirically verifiable fact that in near perfect markets such price differences as do occasionally arise, and which cannot be established as associated with quality or extra-cost differences, are rapidly erased by the operation of market forces. For this

the Theory of Comparative Costs", Economic Journal, Vol. LXII, September 1952, pp. 490-492, suggests that it may be reasonable as a first approximation to posit a unique association between particular relative prices and quantities so as to generate what he calls a "demand substitution curve". If such a curve were expressed in logarithms, its slope would be a measure of constant elasticity. But whether or not expressed in this way, it hardly seems reasonable to assume that a schedule of this kind can be constructed. For, after all, we are dealing with changes in pairs of export prices and quantities. To impose the constraint of unique associations of such pairs amounts to saying that it is possible to specify a function which takes account not only of movement along a given demand schedule, in this case $A$ 's, but also of shifts of the demand schedule for ( $B$ 's) substitutes. As a comparison of Charts 2 and 3 will reveal, there is no a priori reason why such a "demand substitution curve" need even be negatively sloped.

13. If $B$ 's supply schedule was assumed to be infinitely elastic, there would be no problem because the shift to $D_{B}^{\prime}$ would in effect leave $B$ 's export price unaltered at $P_{B}$. 


\section{Chart 3}

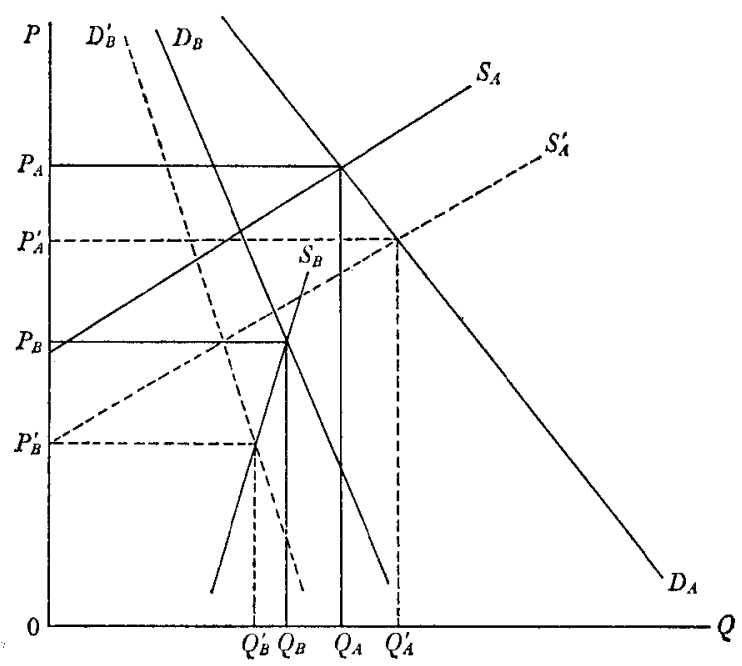

reason, attempts to measure elasticities of substitution between the same or related grades of primary products exported by different countries are devoid of meaning.

In the case of less homogeneous goods traded in imperfect markets, less rapid adjustments are to be expected. This does not make the computed measures any more acceptable, however, because one cannot be sure of the time point which is captured in the price and quantity observations. Since the observations may lie at different positions in the equilibrium process, there is no way to evaluate the differences between the true and the actually computed elasticities, unless the initial disturbance and the consequent market adjustments can be specified and dated ${ }^{14}$. The difference between homogeneous

14. Since the information required for the specification and dating of the price and quantity changes may be difficult to obtain, the likelihood of obtaining meaningful estimates of substitution elasticities does not appear great. This suggests that it would be of considerable interest to study the effects of a disturbance such as a devaluation or a significant and thus readily identifiable change in productivity through a period of time broken into short intervals of months or quarters. The changes should be fairly pronounced, for otherwise the adjustment of market forces would not be so obviously reflected in the recorded data. The observed changes in price differentials and market shares would thus provide insight into 
and non-homogeneous goods is thus one of degree rather than of kind when it comes to measuring substitution elasticities. In neither case is it theoretically defensible to use observed price differentials as a variable to explain the observed variations in quantity.

\section{II}

The foregoing remarks were directed against attempts to estimate substitution elasticities using time series data. Perhaps a way to avoid the difficulties mentioned would be to use cross-sectional analysis, as MacDougall did in his pioneering effort to measure the influence of relative prices on the export performance of the United States and United Kingdom ${ }^{15}$. Although MacDougall dealt with a number of different questions in his two articles, a very considerable amount of his efforts was devoted to examining the relationship between export quantities and prices. This was especially the case insofar as he was interested in and did obtain elasticity estimates which were substantially above those yielded by the conventional time series approach. For the purpose of his analysis he selected a relatively large sample of American and British manufactured goods exports, and fitted linear regressions of the logarithms of relative export quantities and relative export unit values for individual commodity cross-sections for $1913,1922-193^{8}$, and 1948 . The results for $1922-193^{8}$ are summarized in Table $\mathrm{I}$.

The exact meaning of the regression coefficient (slope) which relates the relative prices and quantities of a basket of different goods for a particular year is not entirely clear ${ }^{16}$. On the one hand, MacDougall conceives of the regression coefficient as a weight attached to the explanatory relative export price variable, and says that it would be a "bold step" to interpret it causally to indicate by

the adjustment process which hitherto has been taken for granted in most studies. Focusing upon different time points would then permit assessment of substitution relationships at intervals of various lengths, and would thus make it possible to distinguish more clearly between the equilibrium process and the outcome of market forces.

I5. G.D.A. MacDougall, op.cit., Economic Journal, Vol. LXI, December I95I, and Vol. IxIr, September 1952.

16. See R.J. Nichorson, "Product-Elasticities of Substitution in International Trade”, Economic Journal, Vol. Lxv, September I955, esp. pp.442-444. 
Table I

Correlation Between Logarithms of American and British Relative Export Quantities and Relative Prices of Selected Manufactured Goods, I922-1938

\begin{tabular}{|c|c|c|c|c|}
\hline Year & $\begin{array}{l}\text { Number of } \\
\text { Manufactures }\end{array}$ & $\begin{array}{c}\text { Correlation } \\
\text { Coefficient } \\
(\boldsymbol{r})\end{array}$ & $\begin{array}{c}\text { Regression } \\
\text { Cuefficient } \\
\text { (Slope) }\end{array}$ & $\begin{array}{c}\text { Rate of Exchange } \\
\text { Pounds to Dollars } \\
\text { I929 }=\text { Ioo }\end{array}$ \\
\hline 1922 & 86 & $-0.4 \mathrm{I}$ & -2.0 & 9 I \\
\hline 1923 & 86 & -0.40 & -1.8 & 94 \\
\hline 1924 & 86 & -0.43 & - I.9 & $9^{\text {I }}$ \\
\hline 1925 & 86 & -0.47 & -2.2 & 99 \\
\hline 1925 & 97 & $-0.4^{8}$ & $-2 . I$ & 99 \\
\hline 1926 & 97 & $-0.5^{\circ}$ & -2.4 & IOo \\
\hline 1927 & 97 & -0.54 & -2.4 & IOO \\
\hline 1928 & 97 & -0.55 & -2.5 & roo \\
\hline 1928 & 109 & $-0.5^{6}$ & -2.5 & 100 \\
\hline 1929 & rog & -0.57 & -2.6 & 100 \\
\hline 1930 & 109 & $-0.5^{8}$ & -2.6 & 100 \\
\hline I 93 I & 109 & $\longrightarrow 0.66$ & -2.7 & 93 \\
\hline 1932 & 109 & -0.62 & -2.6 & 72 \\
\hline I933 & Io9 & -0.65 & -2.8 & 87 \\
\hline I 934 & 109 & -0.68 & -3.2 & 104 \\
\hline I935 & IO9 & -0.64 & -3.0 & IOI \\
\hline $193^{6}$ & I 09 & -0.67 & -2.9 & 102 \\
\hline 1937 & IO9 & -0.65 & -3.1 & 102 \\
\hline I $93^{8}$ & 109 & -0.68 & -3.1 & IOI \\
\hline $1934^{-1} 93^{8}$ & I 09 & -0.73 & -3.6 & 102 \\
\hline
\end{tabular}

how much relative quantity would change with some given change in relative price ${ }^{17}$. But on the other hand, he proceeds at least tentatively to "take the plunge" and to interpret the regression co-efficient as an elasticity of substitution ${ }^{18}$. MacDougall's hesitation is under-

I 7. G. D.A. MacDougall, op.cit., Vol. LXII, p. 487 .

18. Ibid., p. $49^{\circ}$. 
standable, but in our view the plunge could hardly be avoided without depriving the regression results of any significant economic meaning.

It does not seem unreasonable, therefore, to construe MacDougall's results as purporting to indicate that the elasticity of substitution between British and American exports of manufactures ranged from slightly under - 2.0 to slightly above -3.0 during 1922-1938, and, further, to understand MacDougall as concluding from these results that relative prices played an important role in determining the export performance of the competing countries ${ }^{19}$.

As before, this conclusion depends upon the meaningfulness of the price data used. It is obvious that the cross-section approach would be invalid in the homogeneous goods case illustrated in Chart I, where at any point in time the price ratio would be unity. Although he never states it explicitly, this may be the reason why MacDougall chose to study manufactured goods exports. Does he, consequently, obviate the difficulties we have discussed? Our answer is no, for at any particular time, MacDougall's cross-sections are catching actual prices, which, because they may represent the outcome of the market process, may not be an accurate indicator of the disequilibrating or "impact" prices that are required to compute the true elasticity of substitution $^{20}$.

19. That MacDougall became less equivocal in interpreting his results is evident from the following quotation taken from his The World Dollar Problem, London 1957, pp. 565-566: "The present author, using a method that avoids time series altogether, has estimated that the long-run elasticity of substitution between U.S. and U.K. exports of manufactures may be of an order approaching $3, \ldots$ ' Italics are in the original text. MacDougall then proceeds to extrapolate these prewar relationships into the postwar period (pp. 565-569).

In an article in process by Robert M. STERn, "British and American Productivity and Comparative Costs in International Trade", some very rough computations for $195^{\circ}$ and 1959 based upon a small sample of U.S. and U.K. manufactured goods exports yielded "elasticities of substitution" of between -1.4 and -1.9. These results, which are considerably below those of MacDougall listed in Table I, make us rather skeptical of extrapolating interwar relationships to the postwar period, especially when they rest upon such an uncertain base.

20. How then should one interpret the results obtained by MacDougall? In the absence of the raw price and quantity data used by him, we are not in a position to answer this question. It would appear, nonetheless, as R.J. Nicholson, op.cit., 


\section{III}

The purpose of our remarks has been to question the theoretical soundness of the base underlying empirical studies of the influence of relative prices on international trade. The argument has been that the observed prices of countries' exports are of little use, and may actually be misleading, in attempting to explain observed changes in export volumes. The reason is that these prices are not likely to reflect fully the disequilibrating, or "impact", price differences in the movement of a market to a new equilibrium. While this is most apparent for homogeneous commodities traded in near-perfect markets, where it will not be uncommon for the relative price ratio to be unity, it is equally applicable to less homogeneous goods traded in imperfect markets. It is difficult under these circumstances, therefore, to place much reliance on computed elasticities of substitution, or on the substantive findings of those studies in which these elasticities play a leading role.

It should be made clear that our argument does not relate simply to the statistical defects of the available data. We emphasize this because it is a common conception that matters would be improved

p. 44 points out, that MacDougall's findings cannot be interpreted as an elasticity of substitution in the conventional sense because of the use of a basket of commodities. But the findings might, alternatively, be interpreted as an empirical average and static elasticity of substitution. However, we remain uncertain about the economic meaning to be attached to such a measurement.

We have been struck, in particular, in examining the actual results listed in Table $I$, by the fact that the regression coefficients for adjacent years are in most cases practically identical; and further, that the results for the average of the years, 1934-1938, are substantially higher than for the individual years considered separately. The empirical near-identity raises the questions of the extent to which the equal weighting of the goods in each year's sample makes for more uniform results, and to what degree the constancy of the non-price factors may be reflected in the observed prices. These points just made may have some bearing on ARNOLD C. Harberger's statement in his "Some Evidence on the International Price Mechanism", p.5II: "If MacDougall has not estimated an elasticity of substitution, he has at least found a striking empirical regularity, for which there should be an explanation". As for the higher coefficients for 1934-1938, they might perhaps be traceable to the understatement of the impact price differences, which, in the observed data, may appear smaller because of the working of market forces. 
greatly if only better data could be had ${ }^{21}$. The preceding analysis suggests, however, that even if it were possible to wash the data clean, observed price ratios would still have no explanatory significance in this context. We would question the desirability, therefore, of carrying out additional studies employing the same methods, and of using scarce resources to develop "purer" data.

The significance of this conclusion for empirical research in international economics cannot be overestimated. Elasticities of substitution have been used as a basis for determining the efficacy of devaluation and for measuring a country's price competitiveness in world trade. Since these problems are central to both international trade theory and policy, it would appear desirable, in view of the defects of the observed data, to devote more effort to the development of alternative methods of analysis that are more nearly capable of uncovering the disequilibrating price differences which are responsible for observed changes in export market shares.

University of Michigan Ann Arbor (USA)

The City College of New York New York (USA)
ROBERT M. STERN

ELLIOT ZuPNICK

SUMMARY

There have been in the postwar period a number of studies which have attempted to measure the elasticity of substitution in the international trade of competing countries. While these studies have been criticized severely on statistical grounds, their theoretical foundation has provoked little discussion. It is our contention that this foundation cannot be supported with much confidence because the price observations which have been used to explain the observed changes in

21. "One trouble is that the quality, design, etc., of products falling into comparable categories in the two trade returns are not always the same, and the proportion exported by each country may differ. If sufficient information were available, the figures could, in principle, be adjusted. In some cases this could be done fairly precisely, e.g., where there were well established grades (as with wheat), with fairly constant price differentials; but with manufactures the adjustment could only be rough and ready'. G. D. A. MACDougall, op.cit., Vol. LXI, p. 718. See also Morgan and Corlett, op.cit., p. 3 I3. 
trade have little or no significance. This is because these prices, which have been computed from the recorded information available, do not accurately reflect the price differentials which are in fact responsible for the observed changes in trade. That is, because of the tendency of the actual prices of substitutable goods to move in sympathy with one another, it is not possible to obtain from the actually recorded observations the ex-ante or impact price differentials required in order to compute the true elasticities of substitution.

The objection to the use of observed prices applies to the analysis of both homogeneous goods traded in perfect markets and to non-homogeneous, albeit substitutable, goods traded in imperfect markets. The differences in the types of goods are merely differences of degree. Moreover, it is contended that neither time series nor cross-section analyses escape our basic objection insofar as they both rely upon actual prices which may represent the outcome of the market process rather than the disequilibrating forces which set this market process into motion.

Since our objection would become even more applicable if the available data were cleansed of statistical impurities, we question the fruitfulness of undertaking additional studies using the same methods and purer data. Since elasticities of substitution are vital in determining the efficacy of devaluation and for measuring a country's price competitiveness in world trade, it is imperative to seek the development of alternative methods of analysis which can more effectively uncover the disequilibrating price differences which are responsible for observed changes in the relative volumes of international trade.

\section{ZUSAMMENFASSUNG}

In der Nachkriegszeit sind mehrere Untersuchungen durchgeführt worden, in denen der Versuch unternommen ist, Substitutionselastizitäten im internationalen Handel zwischen konkurrierenden Ländern $\mathrm{zu}$ messen. Während diese Untersuchungen anhand von statistischen Unterlagen ernsthaft kritisiert worden sind, hat die theoretische Begründung nur wenig Diskussionen ausgelöst. Im obigen Aufsatz wird dargelegt, dass diese Begründung nicht viel Vertrauen einflösst, da die als Unterlagen verwendeten Preisangaben wenig oder gar keinen Aussagewert haben. Der Grund liegt darin, dass die Daten die genauen Preisveränderungen nicht wiedergeben, die tatsächlich für die beobachteten Schwankungen des Handels verantwortlich sind. Wegen der Tendenz der tatsächlichen Preise von Substitutionsgütern, sich parallel zu verändern, ist es nicht möglich, aus den vorliegenden Beobachtungen die benötigten Ex-ante Preisunterschiede zu erhalten, aus welchen die wirkliche Elastizität berechnet werden muss.

Der Einwand gegenüber der Verwendung beobachteter Preise bezieht sich sowohl auf die Analyse homogener Waren auf vollkommenen Märkten und auf nicht homogene, jedoch ersetzbare Güter sowie auf Waren, die auf unvollkommenen Märkten gehandelt werden. Die Unterschiede der verschiedenen Arten von Gütern sind nur gradueller Natur. Überdies wird behauptet, dass 
weder Zeitreihen noch Querschnittsanalysen diese Einwände widerlegen, insofern sie sich beide auf tatsächliche Preise beziehen, die das Resultat des Marktmechanismus statt der ungleichgewichtigen Kräfte widerspiegeln, die diesen Marktprozess in Bewegung setzen. Da die Einwände noch mehr zutreffen, wenn die erhältlichen Daten von statistischen Fehlern bereinigt wären, ist es fraglich, ob weitere Forschungen auf Grund gleicher Methoden und exakterer Angaben überhaupt einen Sinn hätten. Da die Kenntnis der Substitutionselastizität wesentlich für die Beurteilung der Wirksamkeit einer Währungsabwertung und für Vergleiche der Konkurrenzfähigkeit auf dem Weltmarkt dringend notwendig ist, müssen andere Methoden der Analyse entwickelt werden.

\section{RÉSUMÉ}

Dans la période d'après-guerre un nombre d'enquêtes ont été publiées, évaluant les élasticités de substitutions dans le commerce international entre pays concurrants. Tandis que ces études étaient sévèrement critiquées par rapport aux données statistiques, leur fondation théorique n'entraina que peu de discussions. Dans l'exposé ci-dessus, cette fondation ne peut être soutenue avec beaucoup de confiance, étant donné, que les changes notés, employés comme base ont peu de valeur affirmative. C'est que ces prix, calculés d'après des informations obtenues, ne reflètent pas exactement les fluctuations qui sont au fait responsables pour les changes observés dans le commerce. Vu que la tendance des prix actuels pour la marchandise substitutionelle à se modifier parallélement, il n'est pas possible, de conclure des observations donnés, desquelles la vraie élasticité doit être déduite.

L'objection vis-à-vis de l'emploi des prix observés s'applique aussi bien à l'analyse des marchandises homogènes dans des marchés parfaits, qu'à des marchandises non-homogènes, toute fois remplaçables ainsi qu'à des trafics dans des marchés imparfaits. Les distinctions entre les différents types de marchandises sont graduelles. De plus on affirme que ni séries temporaires ni analyses transversales peuvent contester ces objections, en tant qu'elles se réfèrent à des prix fondés, qui reflètent le résultat du mécanisme du marché au lieu des forces déséquilibrées, qui mettent ce procès du marché en mouvement. Etant donné que ces objections s'avèrent encore plus appropriées au cas, où ces donnés seraient exemptes de fautes statistiques, il est douteux si des recherches basées sur les mêmes méthodes et des données plus précises auraient un sens. Comme la connaissance de l'élasticité substitutionelle est essentielle pour le jugement de l'efficacité d'une évaluation monétaire et pour des comparaisons de la capacité concurrencière dans le marché mondial, il est nécessaire que d'autres méthodes d'analyse soient développées. 